\title{
THE INFORMATION CONTENT OF SHARE REPURCHASES - EVIDENCE FROM POLAND
}

\section{Elżbieta Wrońska-Bukalska, Bogna Kaźmierska-Jóźwiak, Jiří Rozkovec}

\section{Introduction}

Share repurchase is a phenomenon that has recently been thoroughly studied around the world. Despite being seen as a substitution for dividends and a tool for distributing excess cash, it would appear that there are more reasons for repurchasing shares and more complex problems than only distributing excess cash to shareholders. The bulk of the research concerns the market reaction to the announcement and implementation of share repurchase programmes. We attempt to ascertain the market reaction to the announcement of share repurchases and to determine the reasons for the reaction. We assume that share repurchase programmes might be explained by the agency theory or signalling theory. We expect that share repurchases convey valuable information to the investors because of the separation of ownership and management. We seek to identify what kind of information the share repurchase conveys.

Although we are aware that a considerable amount of research concerning share repurchases already exists (including the situation in Poland), the originality of our approach is that we conducted our research into an alternative system of trading on the Warsaw Stock of Exchange (WSE): NewConnect. All of the research for Polish companies thus far has concerned the main market of the Warsaw Stock Exchange. We are the first to undertake research into the alternative trade system (NewConnect). The main market of the WSE has been in operation since 1990 and is dedicated to big and mature companies with a capitalization of over 15 million euros. At the end of 2016 approximately 400 companies were listed. Obviously, such companies are ready to distribute cash to shareholders. NewConnect began in 2007 as an alternative to trading on the WSE and is dedicated to innovative, growing companies with prospects of further intense growth; 400 companies are listed. The NewConnect is dedicated to relatively small companies with higher investment risks (Pauka \& Żyła, 2017). According to Damodaran (2001, p. 927) companies in a growth stage have no incentive to get rid of cash (as a dividend or a share repurchase). The phenomenon of growth companies transferring cash was the basis of our interest in share repurchases on NewConnect.

Our research contributes to the payout policy and one of the greatest values is its attempt to identify the market reaction to share repurchases implemented by young, small and innovative companies in an emerging economy and attempt to explain what information is conveyed by a share repurchase announcement.

64 buyback implementations over the period 2007 to 2016 were identified and an analysis was carried out on them. No database is available, so all the data was gathered by the authors manually. In this study, cumulative average abnormal returns were applied to identify the market reaction (dependent variable). We try to explain the market reaction by employing the signalling and the agency theory. In investigating the factors which drive investors' behaviour we applied the regressions model. We employed some explanatory variables describing the agency theory and signalling hypotheses: relative payout, market to book ratio, operational cash flow, and debt ratio. The hypotheses are formulated in section 1.

The rest of the paper is organized as follows: section 1 presents a review of literature on share repurchase and the market reaction and reasons to implement share repurchase. Section 2 presents the data and methodology, variable description and statistics about the 
sample in this study. Section 3 presents empirical data and analysis; in particular the cumulative abnormal returns around share repurchase results. Section 4 presents the results and discussion of the multivariate regression analysis. The paper is then summarized in Section 5.

\section{Literature Review}

Announcements of open market repurchase programmes have recently become common not only in the United States but also in many other countries. Despite the fact that a large number of researchers have empirically analysed share repurchase programmes, several pertinent questions remain valid: How does the share price react to repurchase announcements? What determinants does the price reaction depend on?

Our research problems stems from the Fama's (1970) efficient market hypothesis $(E M H)$, which states that prices in the market incorporate and reflect all relevant information which may impact a stock.

Most of the research, inter alia Asquith and Mullins (1986), Comment and Jarrell, (1991), Ikenberry et al. (1995), McNally (1999), Kahle (2002), Hackethal and Zdantchouk (2006), Wang and Johnson (2008), Rau and Vermaelen (2002), Będowska-Sójka (2003), Gryglewicz (2004), Gurgul and Majdosz (2005), and Pieloch (2011), demonstrates that the announcement of a share repurchase could be a strong signal to the capital market, and could trigger a statistically significant increase in the market prices of the shares.

Empirical results of cumulative average abnormal returns (CAAR) following share repurchase announcement programmes indicate that the results vary across different countries. For example for Germany and Japan, CAAR is about $6 \%$, for the United States, Australia, Canada and Korea it is much lower - approximately $3 \%$, while the United Kingdom and Hong Kong are at the lowest end at around $1 \%$ cumulative average abnormal return (Hackethal \& Zdantchouk, 2006, p. 131). These effects are relatively high in Poland 5-6\% (Będowska-Sójka, 2003; Gryglewicz, 2004). The market reaction to share repurchase announcements means that investors are convinced that the stock markets are efficient and the share repurchase programmes convey important information. The market reaction proves that share repurchase announcement enhance stock market efficiency (Busch \& Obernberger, 2017).

There are several theories that interpret the observation that open market share repurchase announcements are associated with positive abnormal stock return, such as information signalling theory and agency theory. In signalling models, as proposed by Bhattacharya (1979) and Miller and Rock (1985), cash transferred to shareholders conveys some positive information about a firm's future earnings. Asquith and Mullins (1986), Ikenberry et al. (1995) and D'Mello and Shroff (2000) argue that signalling theory is the most important explanation for share repurchase announcement returns in the U.S. According to the signalling hypothesis, firms repurchase their shares in order to signal that the firm is currently undervalued (Mitchell \& Robinson, 1999; Mitchell \& Dharmawan, 2007; Akyol \& Foo, 2013). Therefore, the likelihood of a repurchase should be greater for companies with a lower valuation (as measured by Tobin's $Q$, the market-to-book ratio, or previous share price performance), and it should be greater when informational asymmetries between managers and investors are more pronounced. Ikenberry et al. (1995) observe a strong negative relationship between the market-to-book ratio prior to a share repurchase announcement and the magnitude of positive abnormal returns thereafter. The share price reaction caused by a repurchase announcement should be inversely related to the measures of valuation and informational asymmetry.

Another aspect of share repurchase motivations which explains abnormal returns is related to agency conflicts and the free cash flow hypothesis (Jensen, 1986; Easterbrook, 1984). Agency problems usually refer to a conflict of interest between a company's management (agents) and the company's stockholders (principals). Cash distributed either in dividends or through share repurchase programmes reduces the likelihood that managers will invest in projects with a negative net present value, and therefore reduces agency costs. Share repurchases are considered much more volatile and a more discretionary method of cash payout than dividends (Jagannathan et al., 2000). Share repurchases constitute on average much larger payouts than dividends and thus could be a better tool to decrease a company's excess funds. The manager, acting as the agent for 
the shareholders (principals), is supposed to make decisions that will maximize shareholder wealth. But it is in the manager's best interest to maximize his own wealth. The differing aims of agents and principals in such an agency relation give rise to a number of associated costs: hidden information, hidden action, moral hazard, and controlling costs. Agency problems can be mitigated by share repurchases. Share repurchase as a tool for distributing cash flow, diminishing the cash holding and increasing financial leverage reduces the agency costs (Jensen, 1986). By this argument, firms with higher cash holdings, higher levels of free cash flow, fewer profitable investment opportunities (as measured by Tobin's $Q$ or the market-tobook ratio), or lower leverage, should be more likely to announce a repurchase programme. The market should also react more positively to share repurchase announcements made by these companies.

There has been some research explaining the determinants of market reaction to share repurchase announcements. The study of Gan et al. (2017) on Chinese market reveals that the market responds most favorably to repurchases that are announced by high-growth and undervalued firms but the market reaction is not related to profitability, leverage, price to earnings ratio and executive stock options. The empirical evidence of the research conducted on the German market by Hackethal and Zdantchouk (2005) strongly favors the undervaluation signal hypothesis and thereby confirms the results obtained for U.S. market (Ikenberry et al., 1995; Comment \& Jarrel, 1991). The results of the studies conducted on the Polish market do not support the undervaluation hypothesis.

Gryglewicz (2004) investigated market reaction to announcements of share repurchases and dividends on the Polish market (1997-2000) and analysed what factors determine the market reaction. His study confirmed that market reacts positively to announcements of both payout instruments, however the average abnormal returns are higher for share repurchases than for dividends (6\% versus $2 \%$ ). The conducted regression analysis confirmed that only one factor - the amount of payout is statistically significant. Therefore Gryglewicz (2004) concluded that „excess returns seem to be driven solely by the amount of cash distribution regardless of the method used". Będowska-Sójka (2003) conducted research on share repurchases announced on the Polish market over the period 1998-2002. Her results of regression analysis show that there is a stronger market reaction to the announcement of share repurchase published by smaller companies which are characterized by greater information asymmetry. She confirmed also a positive market reaction to the repurchase of a greater share stake.

The study adopted the explanatory variables recommended in the literature. Tab. 1 refers to the relationship between the discussed theories and selected variables which could determine cumulative abnormal returns surrounding the date of open market repurchase announcements.

With regard to prior research, we formulated the following hypotheses:

H1: the relative payout level is positively related to abnormal returns following an announcement of open-market repurchase programmes;

H2: the market to book ratio level is

\section{Tab. 1: Relationship between discussed theories and selected variables}

\begin{tabular}{l|l|c}
\multicolumn{1}{c|}{ Variable } & \multicolumn{1}{c}{ Theory } & Expected sign \\
\hline Amount of payout & Signaling hypothesis/ agency theory & $+/-$ \\
\hline Market to book ratio & Signaling hypothesis & - \\
\hline Operational cash flow & Agency theory (agency costs of free cash flow) & + \\
\hline Debt ratio & Agency theory (marginal cost of external financing) & - \\
\hline
\end{tabular}


negatively related to abnormal returns following an announcement of open-market repurchase programmes;

H3: the operational cash flow level is positively related to abnormal returns following an announcement of open-market repurchase programmes;

H4: the debt ratio level is negatively related to abnormal returns following an announcement of open-market repurchase programmes.

To reiterate, in this paper we attempt to determine the market reaction to the announcement of share repurchase and the reasons for it. As such, the aim of this paper is to examine the market reaction to the share repurchase announcements and to investigate the reasons for it. But the investigated reasons we connect with two dominant theories: signaling theory and agency theory.

While the problem in literature and in previous research is not new, our research is focused on an alternative trading system to the Warsaw Stock Exchange - NewConnect. The main market of the Warsaw Stock Exchange has been in operation since 1990 and is dedicated to big and mature companies with a capitalization higher than 15 million euros. Currently there are approximately 400 companies listed on the main market Warsaw Stock Exchange. The alternative trading system, NewConnect, on the other hand, has been operating since 2007 and is dedicated to innovative, growing companies, with prospects for further intense growth, with almost 400 companies listed.

According to the business life cycle concept, young and growing companies should not get rid of cash, and if a company buys its shares back, the main reason is to signal good investment opportunities.

\section{Methodology}

The research sample is constructed by identifying all the announcements of intention to repurchase shares reported by companies listed on NewConenct, which were then implemented. The data are collected manually by analysing all current reports announced by the companies from 30th of August, 2007 through to the 30th of June, 2016 (there were approx. 12,000 current reports analysed). The reason for selecting this time period is because the 30th of August, 2007 is the date when NewConnect has started.
We identified 75 buyback announcements issued by 67 companies from different industries. Of those 67 companies nine announced buyback more than once. In these cases, we focused only on the first share repurchase programme implementation. There were some companies that announced only share repurchase programme without implementing them. Further analysis was also restricted to the buyback programmes that were not only announced but also implemented. Finally the sample contains 64 announcements of share repurchase programmes which were implemented (from the initial group of 67 companies we excluded three companies that announced buyback only, i.e. without actual implementation).

The sample is not a random sample but it comprises all share repurchase programmes that were not only announced but also implemented by the companies listed on NewConnect over the period of 30.08.2007-30.06.2016.

To be included in the sample, the observation had to satisfy the following criteria:

- the company had to be listed on NewConnect during the period January 2007 to June 2016 ;

- the share repurchase was an open market repurchase programme;

- the company disclosed the amount to be spent over the duration of the share repurchase programme;

- the date of the initial announcement was possible to identify.

The data was drawn from the companies' current reports, biannual reports and annual reports, and the regulators' website. There is no available database covering buyback announcements. All the data was handcollected. The financial data refers to the year before the share repurchase was announced.

The aim of our paper is to analyse the market reaction to a share repurchase announcement.

The first step was to calculate the daily returns for both individual shares as well as the market index. The following formula was used:

$$
R_{i t}=\frac{P_{i t}-P_{i(t-I)}}{P_{i(t-I)}} \times 100
$$

where:

$R_{i t}$ - returns on a share $i$ at time $t$,

$P_{i t}$ - price of the stock $i$ at time $t$,

$P_{i(t-1)}^{i t}$ - price of the stock $i$ at time $t-1$. 
The methodology for calculating abnormal returns is based on the work of Brown and Warner (1985). Due the fact that some of the companies were listed on NewConnect during the period shorter than one year, the rate of return adjusted by the market (Brown \& Warner, 1985) was adopted as the basis for the calculations:

$$
A R_{i t}=R_{i t}-R_{m t}
$$

where:

$A R_{i t}$ - abnormal market adjusted returns on stock $i$ at time $t$,

$R_{i t}$ - denotes the stock return of company $i$ for day $t$,

$R_{m t}$ - denotes the market return for day $t$.

Furthermore $i=1, \ldots, n ; t=1, \ldots, T$.

To check the null hypothesis about zero average abnormal returns against the alternative that average abnormal returns are statistically different from zero, a test based on the $t$-statistic was used. We checked the null hypothesis for all the days within the event window.

The Average Abnormal Returns on day $t$ was calculated using the following equation:

$$
A A R_{t}=\frac{1}{n} \sum_{t=1}^{n} A R_{i, t}
$$

where:

$A A R_{t}$ - Average Abnormal Returns on day $t$, $A R_{i t}$ - abnormal returns on stock i at time $t$.

After calculating the average abnormal returns over a given time, the cumulative average abnormal returns (CAAR) was calculated. CAAR from day 1 to day $k$ is defined as:

$$
C A A R_{t}=\sum_{t=1}^{k} A A R_{t}
$$

where:

$C A A R_{t}$ - cumulative average abnormal returns for k-th period,

$A A R_{\text {it }}$ - average abnormal returns on day $t$.

To examine the sources of market reaction to share repurchase announcements, a regression analysis was used. The aim of the regression presented here is to find sources of market reaction upon announcements of share repurchases. The dependent variable is the cumulative average abnormal return (CAAR) surrounding the date of each announcement in the sample.

Finally we used the following regression model:

$$
\begin{aligned}
& C A A R_{i, t}=\alpha+\beta_{1} P A Y_{i, t}+\beta_{2} M T B_{i, t}+ \\
& +\beta_{3} O C F_{i, t}+\beta_{4} D E B T_{i, t}+\varepsilon_{i, t}
\end{aligned}
$$

In our study we focused on four independent variables:

- the relative payout, measured as the value of the announced disbursement scaled by the company's market capitalization five days before the announcement (PAY),

- the market value to book value ratio (MTB), i.e. the relation of the market value to book value from the fifth day before the announcement,

- the operational cash flow variable, calculated by dividing operational cash flow from the year prior to the announcement by the asset value at the end of the previous year (OCF),

- the debt ratio (DEBT), calculated as debt divided by assets form the last quarter before the announcement.

The variable of relative payout (PAY) was used to capture the differences in the size of disbursements among individual announcements. We expected to obtain a positive relation with abnormal returns surrounding the dates of payout announcements.

The market value to book value ratio (MTB) can show the level of under- and overvaluation and therefore can test the undervaluation hypothesis. But the market value to book value ratio is also a measure of investment opportunities. When the MTB is higher than 1.0, then companies can increase their capital stock with a lower cost. They have more investment opportunities (can have more investment projects with a lower rate of return because the cost of capital is lower). We expected to obtain a negative relation with abnormal returns around payout announcements.

The operational cash flow variable (OCF) reflects the cash flow hypothesis of agency theory. The higher the cash flow, the higher the agency costs. In such a case, the decision to distribute cash flow to shareholders can diminish agency costs. We expected to obtain a positive cash flow relation with abnormal 


\begin{tabular}{l|c|c|c|c|c|c|c|c|c|c} 
& $\mathbf{2 0 0 7}$ & $\mathbf{2 0 0 8}$ & $\mathbf{2 0 0 9}$ & $\mathbf{2 0 1 0}$ & $\mathbf{2 0 1 1}$ & $\mathbf{2 0 1 2}$ & $\mathbf{2 0 1 3}$ & $\mathbf{2 0 1 4}$ & $\mathbf{2 0 1 5}$ & $\mathbf{2 0 1 6}$ \\
\hline $\begin{array}{l}\text { Number of } \\
\text { announcements }\end{array}$ & 0 & 1 & 3 & 3 & 11 & 14 & 11 & 17 & 3 & 1 \\
\hline $\begin{array}{l}\text { Total payout } \\
\text { (thousands of EUR) }\end{array}$ & 0 & 189 & 367 & 1,925 & 3,622 & 5,373 & 6,060 & 7,427 & 8,983 & 1,250 \\
\hline $\begin{array}{l}\text { Mean value of share } \\
\text { repurchase payout } \\
\text { (thousands of EUR) }\end{array}$ & 0 & 189 & 122 & 642 & 329 & 384 & 551 & 437 & 2,994 & 1,250 \\
\hline $\begin{array}{l}\text { Median value of share } \\
\text { repurchase payout } \\
\text { (thousands of EUR) }\end{array}$ & 0 & 189 & 125 & 375 & 250 & 343 & 437 & 250 & 243 & 1,250 \\
\hline
\end{tabular}

returns around payout announcements.

The debt ratio (DEBT) estimates the capital structure motives. Companies which are less leveraged have a lower opportunity to benefit from a debt-to-equity ratio. The lower the debtto-equity ratio before the share repurchase, the more there are benefits of increasing debt-toequity ratio and financial leverage. We expected to obtain a negative relation with abnormal returns around payout announcements.

\section{Empirical Data and Analysis}

\subsection{Descriptive Statistics of the Sample}

The basic data describing our sample is included in Tabs. 2 and 3. The data in Tab. 2 presents the frequency and the size of share repurchase programmes on NewConnect.

The first share repurchase programme was implemented a year after NewConnect was established, i.e. 2008. This came four years after share repurchase was permitted in line with the Polish Code of Commercial Companies, and after public companies from the main market of the WSE started to implement share repurchase programmes. The peak of share repurchasing was in the period of 2011-2014, with 53 companies implementing share repurchase programmes and the total cash transferred to shareholders more than $22 \mathrm{~m}$ euros (approximately PLN $90 \mathrm{~m}$ ). The total value of cash transferred to shareholders in 2008-2016 amounted to 35m euros (PLN 140m) by 64 companies.

According to Gryglewicz (2004) a total of $47 \mathrm{~m}$ euros (PLN $188 \mathrm{~m}$ ) were transferred by 36 share repurchasing companies from the main market of the WSE in the four-year period of 1997-2000 alone. Comparing the mean value of share repurchase programmes from the main market of the WSE with those from NewConnect, the former was approximately 1,305,000 euros, while the latter was about 550,000 euros. It is apparent that the mean value of share repurchase programmes on NewConnect is almost three times smaller than that of the main market of the WSE. Even the mean value of IPOs is ten times smaller on NewConnect than on the main market of the WSE.

Tab. 3 provides descriptive statistics of the sample. The descriptive statistics refer to the financial situation of the companies in the year before their share repurchase programme was announced.

There is a wide diversity in the financial standing of share repurchasing companies from NewConnect. The high standard deviation value and the differences between the mean and median prove that it is difficult to describe the average company implementing share repurchase programmes.

Following the definition of small and medium enterprises included in the European Union recommendation 2003/361, we found that most of the companies repurchasing their shares are small and medium. Only 2 out of 64 companies are big (3\%).

Among the companies listed on NewConnect implementing share repurchase programmes there are firms with very high (70) and very low (0.03) liquidity current ratios with an average (mean and median) much higher than the optimal value of 1.8. Similarly, 


\begin{tabular}{l|r|l|r|r|r|r|r}
\multicolumn{1}{c|}{ Ratio } & $\begin{array}{l}\text { N (number } \\
\text { of observa- } \\
\text { tions) }\end{array}$ & \multicolumn{1}{|c|}{ Formula } & \multicolumn{1}{c|}{ Min. } & \multicolumn{1}{c|}{ Mean } & Median & Max. & $\begin{array}{l}\text { Standard } \\
\text { deviation }\end{array}$ \\
\hline $\begin{array}{l}\text { Size I } \\
\text { (thousands of EUR) }\end{array}$ & 64 & Total assets & 42.0 & $6,875.0$ & $2,880.0$ & $112,190.0$ & $14,850.0$ \\
\hline $\begin{array}{l}\text { Size II } \\
\text { (thousands of EUR) }\end{array}$ & 64 & Sales revenue & 32.0 & $5,890.0$ & $2,370.0$ & $52,460.0$ & $10,550.0$ \\
\hline $\begin{array}{l}\text { Liquidity - current } \\
\text { ratio }\end{array}$ & 64 & $\begin{array}{l}\text { Current assets to short term } \\
\text { liabilities }\end{array}$ & 0.03 & 5.8 & 2.9 & 70.4 & 9.7 \\
\hline $\begin{array}{l}\text { Liquidity - } \\
\text { quick ratio }\end{array}$ & 64 & $\begin{array}{l}\text { Cash and receivables to } \\
\text { short term liabilities }\end{array}$ & 0.03 & 4.7 & 2.0 & 7.02 & 9.6 \\
\hline Cash ratio & 64 & $\begin{array}{l}\text { Cash to the investment } \\
\text { expenditure }\end{array}$ & 0.01 & 3.40 & 1.13 & 37.50 & 7.3 \\
\hline ROS (\%) & 64 & Net profit to sales revenue & $-6,971.0$ & -101.0 & 5.1 & 70.0 & 872.6 \\
\hline ROA (\%) & 64 & Net profit to total assets & $-13,520.0$ & -200.6 & 6.4 & 68.0 & $1,691.4$ \\
\hline ROE (\%) & 64 & Total debt to Total Assets & 1.0 & 42.7 & 25.3 & 93.4 & 114.5 \\
\hline Leverage (\%) & 64 & Market value to book value & -0.69 & 3.3 & 1.8 & 33.4 & 5.2 \\
\hline M/BV & 64 & $\begin{array}{l}\text { Operating cash flows to } \\
\text { investment expenditure }\end{array}$ & -214.83 & -2.3 & 0.45 & 17.43 & 27.49 \\
\hline OCF to Investment & & & -77.0 & -11.9 & 8.4 & 125.0 & 225.5 \\
\hline
\end{tabular}

Source: authors' calculations

an analysis of descriptive statistics for quick ratios revealed six companies $(9 \%)$ with current liquidity ratio lower than 1.0. Therefore, we can conclude that when taking liquidity into account, the population of companies is diverse.

Descriptive statistics for profitability ratios also confirm a high disparity and sample diversity. There were seven companies $(11 \%)$ with negative profitability. Although the repurchasing companies were profitable, only 40 out of $64(61 \%)$ never paid dividends while being public (not only in the year that a share repurchase programme was implemented).
Most of the repurchasing companies were only slightly leveraged - using only approximately $30 \%$ of debt. Nine companies $(14 \%)$ had a leverage ratio higher than $50 \%$.

The final conclusion regarding the basic features of the companies repurchasing shares on NewConnect over the period 2007-2016 is that the analysed population is highly diversified in terms of their financial situations. However, this sample diversity might be explained by the relatively long period of analysis (2007-2016) and the changing macroeconomic conditions (including a financial crisis period).

\section{Tab. 4: Cumulative abnormal returns around the share repurchase announcement day}

\begin{tabular}{l|l|l|l|l|l}
\multicolumn{1}{c|}{ Days } & $\mathbf{( - 1 ; + 1 )}$ & $\mathbf{( - 2 ; + 2 )}$ & $\mathbf{( - 3 ; + 3 )}$ & $\mathbf{( - 4 ; + 4 )}$ & $\mathbf{( - 5 ; + 5 )}$ \\
\hline CAAR value & $3.15 \%^{* *}$ & $5.07 \%^{* * *}$ & $4.71 \%^{* *}$ & $4.6 \%^{* *}$ & $6.01 \%^{* *}$ \\
\hline t-statistic & 2.4609 & 2.9084 & 2.6432 & 2.1613 & 2.6388 \\
\hline p value & 0.0167 & 0.0051 & 0.0104 & 0.0346 & 0.0105 \\
\hline
\end{tabular}




\subsection{Market Reaction}

As we expected, the market reacted positively to announcements of share repurchases made by the analysed companies listed on NewConnect. Tab. 4 presents the cumulative average abnormal returns in a 3-, 5-, 7-, 9- and 11-day window centred on the share repurchase announcement dates.

Cumulative average abnormal returns surrounding the date of share repurchase are significant at standard levels of confidence in all the analysed event windows (3-, 5-, 7-, 9-, 11day). The cumulative average abnormal returns drop to their lowest value in the 3-day window - approximately $3.15 \%$, while the highest is in the 11-day window - approximately $6 \%$. The highest statistically significant CAARs value is in the 5-day window (approximately 5\%).

Compared to other studies conducted for the main market of the Warsaw Stock Exchange our results are not high (Gryglewicz, 2004) shows cumulative abnormal returns at about $4.8 \%$ for the 5-day window). However, they do seem to be quite high compared to other studies conducted for more developed capital markets: Ikenberry et al. (1995) present 3.54\% abnormal returns in the 5-day window for the U.S. capital market, Rau and Vermaelen (2002) show $1.1 \%$ in the same day window for British capital market, Dumont et al. (2004) confirm approximately $1.8 \%$ for the Swiss capital market, and Li and McNally (2007) measure $3.6 \%$ for the Canadian capital market.

It should be noted that the value of CAAR during the 3 days surrounding the share repurchase announcement also vary across different countries. For instance open market transactions by US corporations were found by virtually all the studies to result in much smaller abnormal returns of approximately 3\% (Grullon \& Michaelly, 2002) - CAR $(-1 ;+1)=2.7 \%$; McNally $(1999)-$ CAR $(-1 ;+1)=2.5 \%)$. Also, Hackethal and Zdantchouk (2006) observe that open market repurchase announcements are four times higher in Germany than in the USA (approximately 12\%). Our result of $3.17 \%$ is similar to the results confirmed by researchers for the US market but much smaller than the German results.

\section{Tab. 5: Descriptive statistics of independent variables}

\begin{tabular}{l|c|c|c|c|c|c|c} 
& Min. & Mean & Median & $\begin{array}{c}\text { Lower } \\
\text { quartile }\end{array}$ & $\begin{array}{c}\text { Upper } \\
\text { quartile }\end{array}$ & Max. & $\begin{array}{c}\text { Std } \\
\text { deviation }\end{array}$ \\
\hline PAY & 0.0007 & 0.1410 & 0.0913 & 0.0364 & 0.1869 & 1.041 & 0.1653 \\
\hline MTB & 0.0600 & 3.3624 & 1.8196 & 0.9092 & 3.3768 & 36.092 & 5.4154 \\
\hline OCF & -0.4335 & 0.0380 & 0.0001 & -0.0836 & 0.1460 & 0.814 & 0.1972 \\
\hline DEBT & 0.0140 & 0.4269 & 0.2534 & 0.1156 & 0.4229 & 9.337 & 1.1480 \\
\hline
\end{tabular}

Source: authors' calculations

\subsection{Independent Variables}

Tab. 5 presents the descriptive statistics of the data used as independent variables in the regression analysis. The descriptive statistics refer to the financial situation of the companies in the year before a share repurchase programme was announced.

As the results of the descriptive statistics show, the data is highly diversified in terms of all the variables. When we consider the maximum value and the upper quartile for PAY, MTB and DEBT we can observe extremely high differences (for the PAY variable the maximum value is almost 10 times higher than the value from the upper quartile; for the MTB variable the maximum value is more than 10 times higher). But again this might be explained by the sample diversity and the long period of analysis.

To be able to understand better the multivariate regression analysis we calculated the correlation coefficient. Due the fact that the variables are not normally distributed, Spearman rank coefficient was used in this analysis. Tab. 6 shows the correlations between each pair of variables, which measure the strength of the linear relationship between them. 


\begin{tabular}{l|c|c|c|c}
\multicolumn{1}{c|}{ Variables } & PAY & MTB & OCF & DEBT \\
\hline PAY & 1.0000 & & & \\
\hline MTB & $-0.5937^{* *}$ & 1.0000 & & \\
\hline OCF & -0.2416 & $0.3534^{* *}$ & 1.0000 & \\
\hline DEBT & -0.1446 & 0.0129 & 0.2101 & 1.0000 \\
\hline
\end{tabular}

Note: Significant at ${ }^{*} p<0.05,{ }^{* *} p<0.01$

The only statistically significant $(p<0.01)$ relationships are observed between the variables PAY and MTB, and between MTB and OCF. Taking into the consideration the results we might conclude that more undervalued companies listed on NewConnect pay out higher amount of money through share repurchases programmes. On the other hand the companies with higher market value to book value ratio have bigger amount of operating cash flow. Taking into the consideration the results of the correlation matrix presented in Tab. 6, we can conclude that the low correlation of independent variables justifies further analysis.

\section{Results and Discussion}

Firstly, for the estimation of parameters in model (5) a bootstrap method was used due the fact the data is not a random sample and it is also very heterogeneous. So, there was generated 10,000 random subsamples with repetition with 30 observations to precise the distribution of $t$-statistic of regression parameters. For each sample the regression parameters for model (5) were estimated and the corresponding $t$-statistics were saved to build their empirical distributions. Then the original sample was used again and from the data its parameters were estimated and their $t$-statistics were compared with $2.5 \%$ and 97.5\% empirical percentiles from Tab. 7 to test their significance. The dependent variable is the cumulative average abnormal return surrounding share repurchase announcements in 3-, 5-, 7-, 9- and 11-day windows centred on the announcement dates. The explanatory variables are PAY, MTB, OCF, DEBT defined above in section 3 .

The final estimates of regression parameters are presented in Tab. 8. There are also values of Durbin-Watson statistic to test the residual autocorrelation. As all of them are close to 2, there is no autocorrelation.

The results of the analysis indicate that no one analyzed relation between selected variables and cumulative average abnormal returns surrounding share repurchase announcements is statistically significant.

\section{Tab. 7: Percentiles of empirical distributions of t-statistics}

\begin{tabular}{l|c|c|c|c|c|c|c|c|c|c} 
& \multicolumn{2}{|c|}{ CAAR $(\mathbf{- 1 ; + 1 )}$} & \multicolumn{2}{c|}{ CAAR $(\mathbf{- 2} ; \mathbf{+ 2})$} & \multicolumn{2}{c|}{ CAAR $\mathbf{( - 3}+\mathbf{3})$} & \multicolumn{2}{c}{ CAAR (-4) } & \multicolumn{2}{c}{ CAAR (-5; $)$} \\
\hline $\begin{array}{l}\text { Explanatory } \\
\text { variable }\end{array}$ & $2.5 \%$ & $97.5 \%$ & $2.5 \%$ & $97.5 \%$ & $2.5 \%$ & $97.5 \%$ & $2.5 \%$ & $97.5 \%$ & $2.5 \%$ & $97.5 \%$ \\
\hline Constant & -1.23 & 2.82 & -1.92 & 2.54 & -2.01 & 2.94 & -2.20 & 2.83 & -1.47 & 3.37 \\
\hline PAY & -1.71 & 1.51 & -1.53 & 1.75 & -1.91 & 2.02 & -2.60 & 1.94 & -2.59 & 1.50 \\
\hline MTB & -1.97 & 2.07 & -1.46 & 1.98 & -2.78 & 2.30 & -2.38 & 1.08 & -4.17 & 1.23 \\
\hline OCF & -1.94 & 2.75 & -1.88 & 3.92 & -2.06 & 3.88 & -1.81 & 3.18 & -1.28 & 4.02 \\
\hline DEBT & -1.53 & 2.93 & -1.05 & 3.33 & -1.06 & 3.47 & -1.15 & 3.68 & -0.93 & 2.88 \\
\hline
\end{tabular}




\begin{tabular}{|c|c|c|c|c|c|c|c|c|c|c|}
\hline \multirow{3}{*}{$\begin{array}{l}\text { Explanatory } \\
\text { variable }\end{array}$} & \multicolumn{10}{|c|}{$\begin{array}{l}\text { Impact of selected variables on cumulative average abnormal returns } \\
\text { surrounding share repurchase announcements }\end{array}$} \\
\hline & \multicolumn{2}{|c|}{$\operatorname{CAAR}(-1 ;+1)$} & \multicolumn{2}{|c|}{$\operatorname{CAAR}(-2 ;+2)$} & \multicolumn{2}{|c|}{ CAAR $(-3 ;+3)$} & \multicolumn{2}{|c|}{ CAAR $(-4 ;+4)$} & \multicolumn{2}{|c|}{$\operatorname{CAAR}(-5 ;+5)$} \\
\hline & Beta & T-statistic & Beta & T-statistic & Beta & T-statistic & Beta & T-statistic & Beta & T-statistic \\
\hline Constant & 0.035 & 1.64 & 0.043 & 1.55 & 0.043 & 1.48 & 0.069 & 1.98 & 0.087 & 2.44 \\
\hline PAY & -0.040 & -0.35 & -0.038 & -0.26 & -0.045 & -0.30 & -0.170 & -0.94 & -0.166 & -0.89 \\
\hline MTB & 0.000 & 0.12 & 0.001 & 0.19 & $-2.506 \mathrm{E}^{-5}$ & -0.01 & -0.004 & -0.90 & -0.007 & -1.51 \\
\hline OCF & 0.014 & 0.20 & 0.189 & 2.02 & 0.185 & 1.93 & 0.159 & 1.37 & 0.308 & 2.59 \\
\hline DEBT & 0.001 & 0.06 & 0.008 & 0.38 & 0.014 & 0.70 & 0.020 & 0.80 & 0.018 & 0.72 \\
\hline DW-statistic & \multicolumn{2}{|c|}{1.9012} & \multicolumn{2}{|c|}{1.93} & \multicolumn{2}{|c|}{$\frac{1}{1.722}$} & \multicolumn{2}{|c|}{1.704} & \multicolumn{2}{|c|}{1.611} \\
\hline F-statistic & \multicolumn{2}{|c|}{0.092} & \multicolumn{2}{|c|}{1.415} & \multicolumn{2}{|c|}{1.288} & \multicolumn{2}{|c|}{0.802} & \multicolumn{2}{|c|}{2.099} \\
\hline
\end{tabular}

Source: authors' calculations

\section{Tab. 9: Estimates of regression parameters for simple linear regression}

\begin{tabular}{l|c|c|c|c|c|c|c|c|c|c}
\multirow{2}{*}{$\begin{array}{l}\text { Explanatory } \\
\text { variable }\end{array}$} & \multicolumn{2}{|c|}{ CAAR $(-1 ;+1)$} & \multicolumn{2}{c|}{ CAAR $(-2 ;+2)$} & \multicolumn{2}{c|}{ CAAR $(-3 ;+3)$} & \multicolumn{2}{c|}{ CAAR $(-4+4)$} & \multicolumn{2}{c}{ CAAR $(-5 ;+5)$} \\
\cline { 2 - 11 } & Const. & Beta & Const. & Beta & Const. & Beta & Const. & Beta & Const. & Beta \\
\hline PAY & 0.038 & -0.042 & 0.058 & -0.054 & 0.052 & -0.023 & 0.058 & -0.080 & 0.073 & -0.093 \\
\hline $\begin{array}{l}\text { F-Test/ } \\
\text { R-Sq }\end{array}$ & 0.591 & 0.005 & 0.609 & 0.004 & 0.834 & 0.001 & 0.531 & 0.006 & 0.492 & 0.008 \\
\hline MTB & $0.029^{*}$ & $0.001^{*}$ & $0.039^{*}$ & $0.019^{*}$ & 0.040 & 0.003 & 0.048 & -0.001 & 0.065 & -0.001 \\
\hline $\begin{array}{l}\text { F-Test/ } \\
\text { R-Sq }\end{array}$ & 0.720 & 0.002 & 0.278 & 0.019 & 0.408 & 0.011 & 0.900 & 0.000 & 0.752 & 0.002 \\
\hline OCF & 0.031 & 0.024 & 0.043 & 0.201 & 0.042 & 0.189 & 0.041 & 0.144 & 0.050 & 0.264 \\
\hline $\begin{array}{l}\text { F-Test/ } \\
\text { R-Sq }\end{array}$ & 0.711 & 0.002 & 0.020 & 0.084 & 0.032 & 0.072 & 0.176 & 0.029 & 0.018 & 0.087 \\
\hline DEBT & 0.033 & -0.003 & 0.050 & 0.003 & 0.045 & 0.009 & 0.045 & 0.004 & 0.059 & 0.002 \\
\hline $\begin{array}{l}\text { F-Test/ } \\
\text { R-Sq }\end{array}$ & 0.792 & 0.001 & 0.848 & 0.001 & 0.553 & 0.006 & 0.834 & 0.001 & 0.908 & 0.000 \\
\hline
\end{tabular}

Source: authors' calculations

Note: Significant variable at ${ }^{*} p<0.10,{ }^{* *} p<0.05,{ }^{* * *} p<0.01$

In order to examine if one variable alone can show any differences in the market reaction to a share repurchase announcement, we applied a univariate regression analysis by dropping all other variables apart from one. The results are presented in Tab. 9.

The estimates show that the market reacts solely to the MTB in two windows: window $(-1,+1)$ with beta $0.001(p<0.10)$, window $(-2,+2)$ with beta $0.019(p<0.10)$. Therefore the analysis gives an evidence of a significant positive relationship between firm's MTB ratio and both $\operatorname{CAAR}(-1 ;+1)$ and $\operatorname{CAAR}(-2 ;+2)$. However, the findings are contrary to the initial assumption. These results suggest that the higher the market-to-book ratio the higher the expected market reaction to a share repurchase announcement, but only in a very short term the 3-day and 5-day windows.

The results do not support the undervaluation hypothesis on NewConnect, but are in line with Będowska-Sójka (2003) and Gryglewicz (2004) who also did not support the undervaluation hypothesis for the main market of the Warsaw Stock Exchange.

For the remaining variables (PAY, OCF, DEBT), the univariate regression analysis shows no significant impact on market reaction. 
Taking into considerations the results, we should conclude that the study does not support any of the formulated hypotheses. In this way we do not support the hypothesis that young and innovative companies want to signal their undervaluation by implementing buyback programmes, as the companies on more developed countries do (e.g. Ikenberry et al. (1995); D'Mello and Shroff (2000); Mitchell and Dharmawan (2007); Akyol and Foo (2013)).

\section{Conclusions}

This paper investigates the market reaction to share repurchase announcements in Poland and the factors which determine the pattern of the market reaction. The analysis uses a sample of buyback announcements reported by companies listed on NewConnect, a new market financing the growth of young companies with a large growth potential, over the period 2007-2016.

Consistent with expectations, the market reacts positively to announcements of buyback programmes. Our results show that cumulative abnormal returns around the date of a share repurchase are significant at standard levels of confidence in the 3-, 5-, and 7-day event windows centered on the announcement dates. The highest statistically significant value of CAAR is reached in the 5-day window $(5.1 \%)$. Our results do not differ from the findings for the main market of the Warsaw Stock Exchange (Będowska-Sójka, 2003; Gryglewicz, 2004; Gurgul, 2005; Pieloch, 2011).

To examine what determines the market reaction to buyback announcements, firstly a bootstrap method was used. The results of the multivariate regression show no statistically significant relationship between selected variables and the cumulative average abnormal returns surrounding share repurchase announcements.

The findings of the univariate regression point to evidence of a significant positive relationship between a company's MTB ratio and both $\operatorname{CAAR}(-1 ;+1)$ and $\operatorname{CAAR}(-2 ;+2)$. However, the results are contrary to the initial assumption. These findings suggest that the higher the market-to-book ratio, the higher the expected market reaction to a share repurchase announcement, but only in a very short term - the 3-day and 5-day windows. The results do not support the undervaluation hypothesis, as we expected, but are in line with Będowska-
Sójka (2003) and Gryglewicz (2004), who also did not support the undervaluation hypothesis for the main market of the Warsaw Stock Exchange. So, from this point of view, the reaction of NewConnect does not differ from that of the Warsaw Stock Exchange.

Taking into the consideration the results, we should conclude that the study does not support any of the known hypotheses that could explain this market reaction pattern.

However, the authors are aware that the conclusions of the research are limited. Our results could be related to the specific character of the NewConnect market, which as an alternative trading system in Poland is not as transparent as the main market. The second issue is the nature of the companies listed there, which are relatively small with a relatively high level of risk (with limited liquidity of shares).

This paper presents only the initial results of the study on the market reaction to share repurchase announcements, therefore further research should be conducted including other variables, which could explain the abnormal returns surrounding a share repurchase announcement. The limitation of our research indicates that new areas referring to share repurchases are still to be investigated, in particular identifying the differences in market reaction and reasons for market reaction with regard to the life cycle and size of the company, the ownership structure, including in the sample companies from both the main market of the WSE and NewConnect, the alternative trading system to the WSE. It would also be advisable to compare share repurchase implementations against dividend payments.

\section{References}

Andriosopoulos, D., \& Hoque, H. (2013). The determinants of share repurchases in Europe. International Review of Financial Analysis, 27, 65-76. https://dx.doi.org/10.1016/j. irfa.2012.12.003.

Akyol, A. C., \& Foo, C. C. (2013). Share repurchase reasons and the market reaction to actual share repurchases: Evidence from Australia. Journal of International Review of Finance, 13(1), 1-37. https://dx.doi.org/10.1111/ j.1468-2443.2012.01159.x.

Asquith, P., \& Mullins, D. W. (1986). Signalling with Dividends, Stock Repurchases, and Equity Issues. Financial Management, 15(3), 27-44. https://dx.doi.org/10.2307/3664842. 
Będowska-Sójka, B. (2003). Zawartość informacyjna nabywania akcji własnych. Ruch Prawniczy, Ekonomiczny i Socjologiczny, 65(3), 165-180.

Bhattacharya, S. (1979). Imperfect Information, Dividend Policy, and "The Bird in the Hand" Fallacy. The Bell Journal of Economics, 10(1), 259-270.

Brown, S. J., \& Warner J. B. (1985). Using daily stock returns - the case of event studies. Journal of Financial Economics, 14(1), 3-31. https://doi.org/10.1016/0304-405X(85)90042-X.

Busch, P., \& Obernberger, S. (2017). Actual Share Repurchases, Price Efficiency, and the Information Content of Stock Prices. The Review of Financial Studies, 30(1), 324-362. https://dx.doi.org/10.1093/rfs/hhw071.

Comment, R., \& Jarrell, G. A. (1991). The relative signalling power of Dutchauction and fixed-price self-tender offers and open-market share purchases. Journal of Finance, 46(4), 1243-1271. https://dx.doi. org/10.1111/j.1540-6261.1991.tb04617.x.

Damodaran, A. (2001).Corporate Finance. Theory and Practice. New York: Wiley and Sons.

D'Mello, R., \& Shroff, P. K. (2000). Equity Undervaluation and Decisions Related to Repurchase Tender Offers: An Empirical Investigation. The Journal of Finance, 55(5), 2399-2424. https://dx.doi.org/10.1111/00221082.00292.

Dumont, P.-A., Isakov, D., \& Perignon, C. (2004). Stock Repurchases on a Second Trading Line [Working Paper]. University of Geneva.

Easterbrook, F. H. (1984). Two AgencyCosts Explanations of Dividends. The American Economics Review, 74(4), 650-659.

Fama, E. F. (1970). Efficient Capital Markets: A Review of Theory and Empirical Work. Journal of Finance, 25(2), 383-417. https://dx.doi.org/10.2307/2325486.

Gan, C., Bian, C., Wu, D., \& Cohen, D. A. (2017). Determinants of share returns following repurchase announcements in China. Investment Management and Financial Innovations, 14(2), 4-18. https://dx.doi. org/10.21511/imfi.14(2).2017.01.

Grullon, G., \& Michaely, R. (2002). Dividends, Share Repurchases and the Substitution Hypothesis. Journal of Finance, 57(4), 1949-1984. https://dx.doi. org/10.1111/1540-6261.00474.
Gryglewicz, S. (2004). Stock Repurchase as an Alternative to Dividend Payout: Evidence from the Warsaw Stock Exchange [CAF Working Paper no 169]. Centre for Analytical Finance.

Gurgul, H., \& Majdosz, P. (2005). Effect of Dividend and Repurchase Announcements on the Polish Stock Market. Operations Research and Decisions, 1, 25-39.

Hackethal, A., \& Zdantchouk, A. (2006). Signalling Power of Open Market Share Repurchases in Germany. Financial Markets and Portfolio Management, 20(2), 123-151. https://dx.doi.org/10.1007/s11408-006-0011-9.

Ikenberry, D., Lakonishok, J., \& Vermaelen, T. (1995). Market underreaction to open market share repurchases. Journal of Financial Economics, 39(2-3), 181-208. https://dx.doi. org/10.1016/0304-405X(95)00826-Z.

Jagannathan, M., Stephens, C. P., \& Weisbach, M. S. (2000). Financial flexibility and the choice between dividends and stock repurchases. Journal of Financial Economics, 57(3), 355-384. https://dx.doi.org/10.1016/ S0304-405X(00)00061-1.

Jensen, M. C. (1986). Agency costs of free cash flow, corporate finance, and takeovers. American Economic Review, 76(2), 323-329. https://dx.doi.org/10.2139/ssrn.99580.

Kahle, K. M. (2002). When a buyback isn't a buyback: open market repurchases and employee options. Journal of Financial Economics, 63(2), 235-261. https://dx.doi. org/10.1016/S0304-405X(01)00095-2.

Li, K., \& McNally, W. J. (2007). The information content of Canadian open market repurchase announcements. Managerial Finance, 33(1), 65-80. https://dx.doi. org/10.1108/03074350710715818.

McNally, W. J. (1999). Multi-dimensional signaling with fixed-price repurchase offers. Managerial and Decision Economics, 20(3), 131-150. https://dx.doi.org/10.1002/ (SICI)1099-1468(199905)20:3<131::AIDMDE925>3.0.CO;2-A.

Miller, H. M., \& Rock, K. (1985). Dividend Policy under Asymmetric Information. The Journal of Finance, 40(4), 1031-1051. https://dx.doi.org/10.1111/j.1540-6261.1985. tb02362.x.

Mitchell, J. D., \& Robinson, P. (1999). Motivations of Australian listed companies effecting share buy-backs. Abacus, 35(1), 91-119. https://dx.doi.org/10.1111/1467-6281.00036. 
Mitchell, J. D., \& Dharmawan, G. V. (2007). Incentives for on-market buy-backs: Evidence from a transparent buy-back regime. Journal of Corporate Finance, 13(1), 146-169. https:// dx.doi.org/10.1016/j.jcorpfin.2006.12.002.

Pauka, M., \& Żyła, M. (2018). Sygnalizacja wyników finansowych w polityce dywidendowej na rynku NewConnect. Annales Universitatis Mariae Curie-Skłodowska, sectio H-Oeconomia, 51(6), 301-309. https://dx.doi. org/10.17951/h.2017.51.6.301.

Pieloch, A. (2011). Wpływ ogłoszenia decyzji o wykupie akcji własnych na wartość rynkową spółek notowanych na GPW w Warszawie. Finanse, RynkiFinansowe, Ubezpieczenia, 46, 569-579.

Rau, R., \& Vermaelen, T. (2002). Regulation, Taxes, and Share Repurchases in the United Kingdom. Journal of Business, 75(2), 245-282. https://dx.doi.org/10.1086/338703.

Wang, J., \& Johnson, L. D. (2008). Information Asymmetry, Signalling and Share Repurchase [Working Paper]. Kingston: Queen's University.
Elżbieta Wrońska-Bukalska, Ph.D. with habilitation (D.Sc.)

Maria Curie-Skłodowska University in Lublin

Faculty of Economics

Department of Corporate Finance

Poland

elzbieta.bukalska@umcs.lublin.pl

Bogna Kaźmierska-Jóźwiak, Ph.D.

University of Łódź

Faculty of Management

Department of Finance and Strategic Management

Poland

bognakaj@uni.lodz.pl

Mgr. Jiří Rozkovec

Technical University of Liberec

Faculty of Economics

Department of Economic Statistics

Czech Republic

jiri.rozkovec@tul.cz 


\title{
THE INFORMATION CONTENT OF SHARE REPURCHASES - EVIDENCE FROM POLAND
}

\author{
Elżbieta Wrońska-Bukalska, Bogna Kaźmierska-Jóźwiak, Jiří Rozkovec
}

Announcements of open market repurchase programmes have recently become common not only in the United States but also in many other, less developed countries. The aim of the paper is to examine the market reaction to share repurchase announcements and to investigate the reasons for the market reaction. There is a good deal of research referring to the share repurchases, even in Poland, the originality of our approach is that we conducted our research on an alternative system of trading to the Warsaw Stock of Exchange, namely NewConnect. NewConnect is dedicated to young, small and innovative companies. We found it extremely interesting that such companies in need of external financing take the decision to distribute cash and implement share repurchase.

The data was collected for 64 share repurchase announcements over the period 2007-2016. In this study cumulative average abnormal returns are applied to identify the market reaction. To investigate the factors which drive investor behaviour we applied the regressions model. We employed some explanatory variables describing the agency theory and signalling hypotheses: relative payout, market to book ratio, operational cash flow, and debt ratio. We found that cumulative average abnormal returns around the share repurchase date are significant at standard levels of confidence in all the analysed event windows. The results of the multivariate and univariate regression analyses do not support the undervaluation hypothesis, as we expected.

Key Words: Share repurchase, event study, market reaction, signaling theory, agency theory.

JEL Classification: G14, G35.

DOI: 10.15240/tul/001/2018-2-012 